\title{
Would STAT1 GOF prevent severe forms of COVID-19?
}

\author{
Lara Teixeira ${ }^{1}$, Carolina Aranda ${ }^{2}$, Rafaela Guimarães ${ }^{1}$, Luiza Schmid ${ }^{1}$, Mariana Pimentel ${ }^{1}$, \\ Maria Rizzo ${ }^{1}$, Ekaterini Goudouris ${ }^{3}$, and Dirceu Solé ${ }^{2}$ \\ ${ }^{1}$ Federal University of Sao Paulo Allergy Clinical Immunology and Rheumatology Division \\ ${ }^{2}$ Federal University of São Paulo \\ ${ }^{3}$ Universidade Federal do Rio de Janeiro
}

September 21, 2020

Would STAT1 GOF prevent severe forms of COVID-19?

To the Editor:

As the world faces the current SARS-CoV-2 pandemic, the scientific community struggles to answer questions about the disease that have not been fully clarified yet. It is well known that individuals with certain chronic diseases are at higher risk of having worse prognosis when infected with this virus. Although the risk of a severe disease is still a matter of conjecture in subjects with Inborn errors of Immunity (IEI), these patients may present more COVID-19 complications than the general population, either by community acquired or nosocomial infection ${ }^{1}$.

In our immunology referral clinic at the Federal University of São Paulo (UNIFESP), so far, 16 IEI patients have been diagnosed with COVID-19, with a large spectrum of presentation, ranging from mild disease to severe acute respiratory syndrome and death. One of them, however, had a favorable outcome, with no complications, after being infected with the SARS-CoV-2, despite his several serious comorbidities.

We report the case of an 11- year -old boy, diagnosed with Type 1 Diabetes Mellitus at the age of 3 years. At that time, he presented persistent watery diarrhea, 3 to 4 episodes a day. One year later, productive cough, persistent fever, conjunctival hyperemia and generalized lymph node enlargement emerged. Histoplasma sp. was isolated in ocular secretion. Acute Disseminated Histoplasmosis (pulmonary, ocular and ganglionic) was diagnosed and he received Itraconazole for one year.

In 2018, at the age of 9 years, we started to follow him at our immunology clinic. He received all vaccines for his age with no adverse events. The family reported recurrent skin infections, repeated pneumonia, mucocutaneous and esophageal candidiasis, and arthralgia. He presented hepatomegaly and failure to thrive. The main diagnostic hypothesis was a disease of immune dysregulation. Screening for inborn errors of immunity and inflammatory lab tests were performed. White blood cell count, immunophenotyping and lymphocyte proliferation, serum immunoglobulins and dihydrorodamine (DHR) assay were in normal range. HIV serologies were negative. Whole exome sequencing was performed and the variant c.1675G $>\mathrm{C}$ (de novo variant) appeared in the STAT1 gene (Figure 1) ${ }^{3}$, in heterozygosis. To date, no data on this genetic variant has been published. This new finding is probably considered pathogenic and, due to the patient's clinical characteristics, STAT1-GOF is very likely to be the diagnosis of our boy. 


\begin{tabular}{|c|c|c|c|c|c|c|}
\hline Condiçăo clínica & \begin{tabular}{|c|} 
Mecanismo de \\
Heranņ̧a
\end{tabular} & Gene & $\begin{array}{c}\text { Posiçäo } \\
\text { cromossómica }\end{array}$ & Efeito Molecular & Zigosidade & Comentários \\
\hline $\begin{array}{c}\text { Imunodeficiência } 31 \mathrm{~A}, \mathrm{~B} \mathrm{e} \\
\mathrm{C} \\
\text { [OMM: 312865] }\end{array}$ & $\begin{array}{c}\text { Autossómico } \\
\text { Dominante / } \\
\text { Autossômico } \\
\text { Recessivo }\end{array}$ & STATI & $\begin{array}{c}\text { Chr2: } \\
\text { 191.844.550 }\end{array}$ & $\begin{array}{c}\text { ENST00000381099.3. } \\
\text { c.1875G C: } \\
\text { p.(Gu55eGin) }\end{array}$ & Heterozigose & $\begin{array}{l}\text { - Variante confimada por metodologia } \\
\text { ortogonal Sanger no menor Antônio } \\
\text { - Näo identificada nas amostras dos } \\
\text { genitores: sugere evento de novo } \\
\text { - Năo encontrada na literatura médica } \\
\text { - Não encontrada nos bancos de dados de } \\
\text { frequência populacional }\end{array}$ \\
\hline
\end{tabular}

Figure 1

He was admitted to a pediatric hospital two weeks after his first immunology appointment, due to exacerbation of respiratory symptoms. A chest X-ray showed atelectasis in the apex of the right lung, already observed in previous images. Chest tomography $(\mathrm{CT})$ done at this time showed extensive cylindrical bronchiectasis in the upper lobe of the right lung. A group of thoracic surgeons recommended a lobectomy of the right upper lobe for better control of recurrent lung infections. Figure 2 shows the chest CT performed nine months after surgery, during an acute respiratory infection.

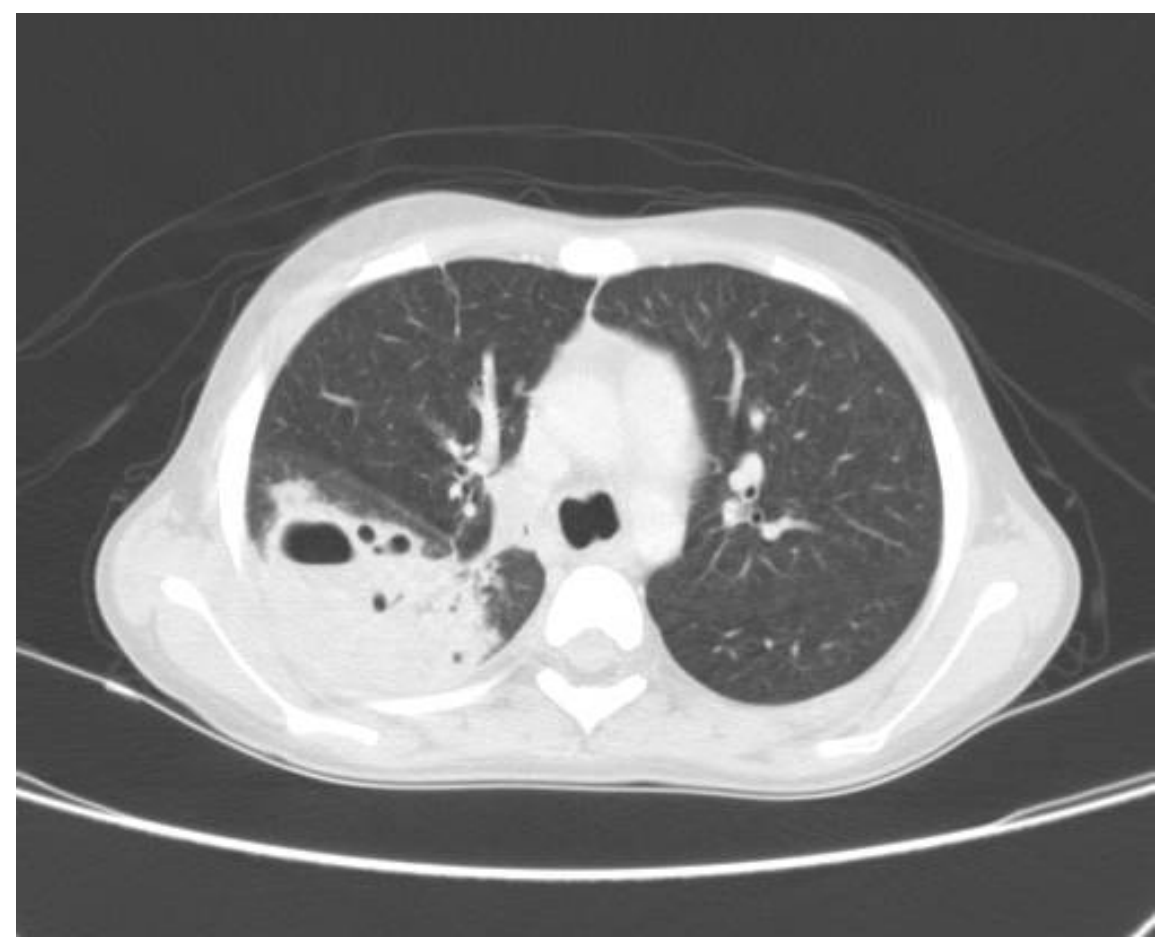

Treatment with a JAK inhibitor has been indicated, but it has not yet been possible to start it.

Figure 2

In April 2020, the child was once again admitted to hospital, complaining of dyspnea and chest pain for three days. His mother and sister had fever and anosmia for a week, with positive RT-PCR for SARS-CoV-2. He had no fever, cough or other respiratory symptoms. Laboratory results showed leukopenia $(3.280 / \mu \mathrm{L})$ and positive RT-PCR for SARS-CoV-2.

He was treated with inhaled salbutamol $800 \mathrm{mcg} /$ day, oral prednisolone $1 \mathrm{mg} / \mathrm{Kg} /$ day, oral azithromycin $250 \mathrm{mg} /$ day and oral levofloxacin $250 \mathrm{mg}$ /day. Oxygen saturation was above $95 \%$ throughout the hospital stay, and glycemic level was satisfactory with human insulin and strict monitoring of a pediatric endocrinologist. Intraconazole prophylaxis was maintained. After ten days of hospitalization, white blood cell count went 
up to $9.710 /$ uL. In addition, he presented D-dimer and interleukin 6 in the normal range (this last was 2.5 , reference value less than $3.4 \mathrm{pg} / \mathrm{mL}$ ). Chest CT did not show ground-glass opacities. Viral RNA load determined by cell culture was present on the seventh day of symptoms. At that same period, IgM against the novel virus was identified.

His nasopharyngeal swab for SARS-CoV-2 was still positive on the $13^{\text {th }}$ day of symptoms and became negative on the 16th day, when antibodies that potentially neutralize SARS-CoV-2 were identified. During all this period, he remained hospitalized, afebrile, with no complaints and without supplemental oxygen.

SARS-CoV-2 is part of a large family of enveloped, single positive-strand RNA viruses ${ }^{2}$. When it enters the cell, its RNA is recognized by the Toll-like-receptors (TLRs): 7/8 and 9 TLR. The result is the activation of different signaling pathways and transcription factors, resulting in the expression of genes, which products are essential for antiviral and inflammatory responses. The 7/8 and 9 TLRs engage the MyD88 adapter leading to activation of the transcription factor $\mathrm{NFkB}$, which induces inflammatory responses. They also signal via the TRIF adapter (TIR domain-containing adapter inducing IFN- $\beta$ ), that activates the interferon regulatory factor, which promotes the production of type 1 interferons (IFN- $\alpha / \beta)$, important for innate antiviral immune responses ${ }^{4}$.

Signal transducers and activators of transcription (STATs) are proteins present in different cell types, involved in multiple functions of the immune system ${ }^{4,5}$. Mutations that lead to the gain of function in STAT1 (STAT1GOF) increase the uncontrolled phosphorylation of this protein by impairing nuclear dephosphorylation. Thus, there is greater production of STAT-dependent cytokines, such as type 1 interferon (IFN- $\alpha / \beta)$ and interferon $\gamma(\mathrm{IFN}-\gamma)$. As already mentioned, the first one has the role in virus defense, and the second helps to fight mycobacteria. In addition, there is greater inhibitory effect on the IL17 pathway ${ }^{4}$.

Therefore, we have the hypothesis that despite the genetic dysregulation, this patient may present some degree of protection against a more severe form of COVID-19. Nonetheless, so far, there are no reports of patients with STAT1-GOF infected with the novel coronavirus in the world, which emphasizes the importance of continuing research on this inflammatory syndrome, as well as on SARS-CoV-2 infection. The patient and his legal responsible consented to the case report.

References

1. Shaker M, Oppenheimer J, Grayson M et al. COVID-19: Pandemic Contingency Planning for the Allergy and Immunology Clinic. The Journal of Allergy and Clinical Immunology: In Practice . 2020;8(5):1477-1488.e5. doi:10.1016/j.jaip.2020.03.012

2. Raoult D, Zumla A, Locatelli F, Ippolito G, Kroemer G. Coronavirus infections: Epidemiological, clinical and immunological features and hypotheses. Cell Stress . 2020;4(4):66-75. doi:10.15698/cst2020.04.216

3. Reference G. STAT1 gene. Genetics Home Reference. https://ghr.nlm.nih.gov/gene/STAT1. Published 2020. Accessed September 7, 2020.

4. Gaffen S. Structure and signalling in the IL-17 receptor family. Nature Reviews Immunology . 2009;9(8):556-567. doi:10.1038/nri2586

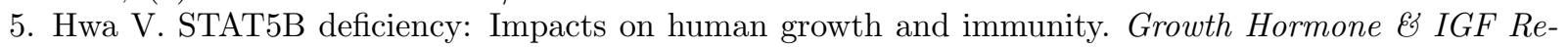
search . 2016;28:16-20. doi:10.1016/j.ghir.2015.12.006

6. Shi Y, Wang Y, Shao C et al. COVID-19 infection: the perspectives on immune responses. Cell Death \& Differentiation . 2020;27(5):1451-1454. doi:10.1038/s41418-020-0530-3

\section{Hosted file}

Figure 1 PAI. docx available at https://authorea.com/users/359960/articles/481709-would-stat1gof-prevent-severe-forms-of-covid-19

\section{Hosted file}

Figure 2- PAI.docx available at https://authorea.com/users/359960/articles/481709-would- 
stat1-gof-prevent-severe-forms-of-covid-19 